\title{
Students' Reflections on the Use of the Zoom Video Conferencing Technology for Online Learning at a South African University
}

\author{
Cedric Bheki Mpungose and Simon Bheki Khoza
}

\begin{abstract}
The majority of universities in South Africa offer face-to-face lectures, resulting in the neglect of online lectures, although learning management systems (LMS) have been adopted and are capable of supporting online learning (e-learning). The coronavirus pandemic (COVID-I9) forced universities to move fully online and to adopt Video Conferencing Technologies (VCT) to supplement LMS for e-learning. However, most students confront challenges related to a digital divide, raising the question of whether universities are able to address these effectively. This study explored students' reflections on the use of the Zoom VCT for e-learning at a South African university. An interpretive qualitative case study was conducted, with data generated using emailed reflective activities and Zoom focus group discussions with 26 students in a curriculum studies programme. The framework of connectivism was employed and the data were thematically analysed. The study found that Internet access was a major challenge. While most students enjoyed synchronous Zoom discussions, they were unable to use other Zoom functions for effective engagement. It is thus recommended that the university should develop an e-learning policy and provide the necessary resources and training to students in order to ensure fitness for purpose.
\end{abstract}

Key words: students' reflections, Zoom VCT, e-learning, face-to-face, curriculum, university

ABOUT THE AUTHORS: CEDRIC BHEKI MPUNGOSE AND SIMON BHEKI KHOZA, University of KwaZulu-Natal, South Africa. Email: Mpungosec@ukzn.ac.za, Khozas@ ukzn.ac.za 
Bien que learning management systems (LMS), systèmes de gestion de l'apprentissage, aient été adoptés et qu'ils soient capables de soutenir l'apprentissage en ligne, la majorité des universités de l'Afrique du Sud offrent des conférences en face-à-face, au détriment de l'apprentissage en ligne (e-learning). La pandémie du coronavirus (COVID-I9) a forcé les universités à virer vers les méthodes en ligne et à adopter les technologies de vidéoconférence (VCT) pour compléter LMS pour l'apprentissage en ligne. Toutefois, la plupart des étudiants font face à des défis liés à une fracture numérique, ce qui soulève la question de savoir si les universités sont en mesure d'y faire face efficacement. Cette étude a exploré les réflexions des étudiants sur l'utilisation du Zoom VCT pour l'apprentissage en ligne dans une université sud-africaine. Une étude de cas qualitative interprétative a été menée, avec des données générées à l'aide d'activités de réflexion par courriel et de discussions entreprises par des groupes de discussion Zoom avec 26 étudiants dans le cadre d'un programme d'études. Le cadre du connectivisme a été utilisé et les données ont été analysées thématiquement. Létude a révélé que l'accès à Internet était un défi majeur. Bien que la plupart des étudiants aient eu des discussions synchrones sur zoom, ils n'ont pas été en mesure d'utiliser d'autres fonctions Zoom pour un engagement efficace. Il est donc recommandé que l'université élabore une politique d'apprentissage en ligne et fournisse les ressources et la formation nécessaires aux étudiants afin d'assurer leur aptitude à cet effet.

Mots clés: réflexions des étudiants, Zoom VCT, apprentissage en ligne, face-à-face, programme d'études, université

\section{Introduction}

Zoom is an online VCT software which facilitates video conferences and meetings. It is the first unified communications application to include meetings, video webinars, conference rooms, and phone and chat functions (Tillman and Willings, 2020). This collaborative resource was developed by Chinese-American businessperson Eric S. Yuan in California in 20II, and was launched in 20I3 (Weiner, 20I7). Zoom is a breakthrough technology that can be used in different sectors, including but not limited to the business sector, industry and higher education (Ahluwalia, 2020). Due to the lockdown measures adopted in response to the 20I0-2020 coronavirus pandemic (COVID-I9), many other VCTs for teaching and learning such as MS Teams, Webex, Blackboard Collaborate Ultra and others were adopted (Strauss, 2020). Zoom is extensively used by universities/schools in developed countries like the United Kingdom, United States of America, Australia, and others, and it has gained popularity with universities in developing countries such as Brazil, India, China, and others (Tillman and
Willings, 2020). In the context of South African universities and schools, it is a new VCT platform which came into widespread use due to the spread of COVID-I9 (Chetty, 2020; DHET, 2020)

On II March 2020 the World Health Organisation (WHO, 2020) declared COVID-I9 a pandemic. South Africa's President called on all universities and schools to close and find ways to offer lectures online as from i8 March 2020 (DHET, 2020). Students were forced to vacate campuses and return home, and Zoom VCT (a plug-in on Moodle LMS) was adopted as a convenient platform for students to engage with lecturers virtually to disseminate content. Given the suddenness of this decision, students did not receive prior training on the Zoom VCT and consideration was not given to their Wi-Fi access. Furthermore, universities lacked an e-learning policy.

The majority of South African students are black, disadvantaged and come from remote areas where Wi-Fi is difficult to access (Mpungose, 2020; Waghid and Davids, 20I9). Using Zoom VCT without pedagogical guidelines in place or proper support for students can severely disrupt teaching and learning (Khoza and Biyela, 20I9; Prensky, 200I).

Furthermore, the digital divide (DD) - the gap between those who have and do not have access to computers and the Internet - is a significant factor that limits the feasibility of using Zoom VCT for teaching and learning in South Africa (Van Deursen and van Dijk, 2019; Warschauer, 2002). The aforementioned authors assert that socio-economic factors, race, social class, gender, age, geographical area and educational background determine the level of the DD in a university context. While students in European and American universities enjoy high levels of access to the Internet and computers, this is not the case in African universities due to the intensity of the factors which led to the DD (Van Deursen and van Dijk, 20I9). The DD can prevent students from using Zoom VCT while at home (Ansaldo, 2020). For example, they may not be able to host and record meetings, participate in group chats, and collaborate with other students. While the Zoom VCT help centre provides tutorial videos on how to use it, lack of Wi-Fi access and other factors can hinder South African students' access to this VCT (Mpungose, 2020; Zoom Support, 2020).

There is a paucity of research on the challenges confronting South African university students in the use of the Zoom VCT, particularly for e-learning. We argue that optimal use of Zoom for e-learning during a lockdown when students are confined to their homes requires that the DD is addressed and that guiding policies on e-learning are developed, including training. In proposing practical solutions to enable South African universities to deal with these challenges, we adopt a connectivism learning framework. 


\section{Theorising the Use of Zoom at University}

Siemens and Downes (2009) developed connectivism (See Figure I below) as a new learning framework for the digital age. This framework highlights the importance of networks and connectedness in integrating online applications (Zoom) in the curriculum (e-learning). Connectivism is an emerging framework that draws on basic learning frameworks (behaviourism, cognitivism, and constructivism) and supports social construction of knowledge. Siemens (2005) notes that it theorises the learning process as the sharing of information among networks of human and non-human channels/artifacts (lecturers, students, hardware and software). Connectivism generates new learning methods, with the focus increasingly shifting from the teacher to more student-centred learning approaches (Anderson, 20I6; Siemens and Downes, 2009). In using the Zoom VCT for learning, connections need to be established between nodes/relationships among individuals, groups, and technological resources. Connectivity (Zoom/the Internet) is a prerequisite to enable each student to participate in online lectures for e-learning, and to gather and share information with others using different technological resources (Bell, 20II; Kop and Hill, 2008). In other words, connectivism requires that students have access to hardware (mobile phone, laptop, workstation and others) and software (Zoom, the Internet and others) resources for effective e-learning (Khoza and Mpungose, 2018)

Figure 1. The Connectivism Learning Framework (Siemens and Downes, 2009)

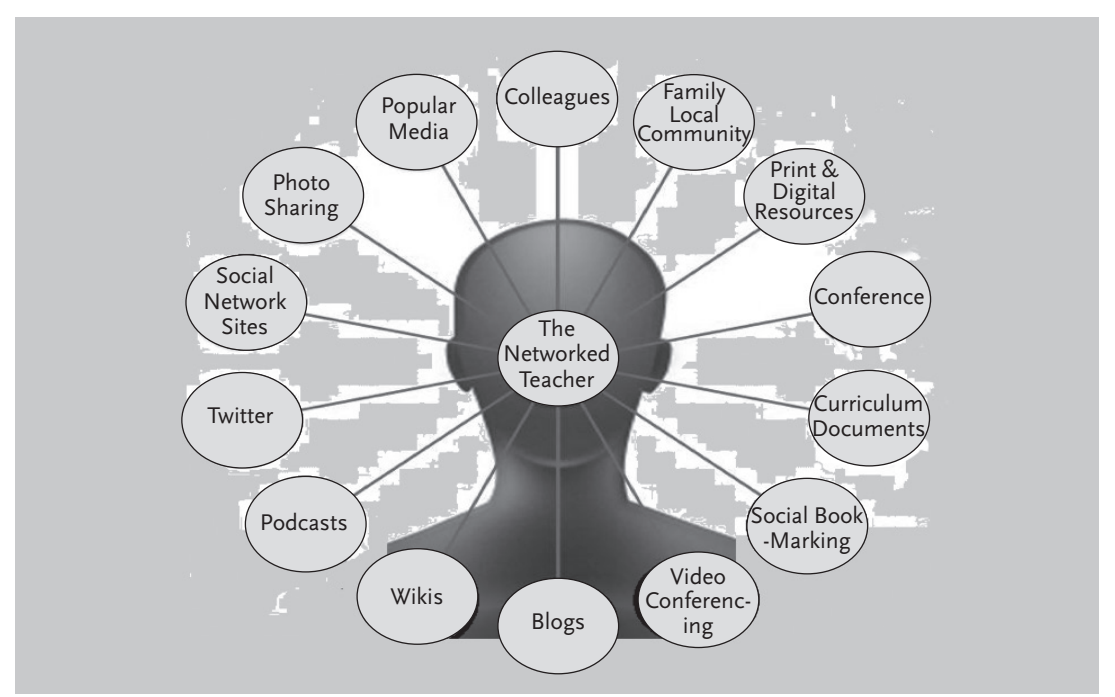

The rapid development and adoption of new VCT (Zoom) enables learning to be individually and socially constructed by students (student-centred activities) to promote diverse ideas (Downes, 2010). This suggests that in e-learning through Zoom, students should actively participate in knowledge construction. The active student has the ability to use resources to seek out current information from primary and secondary sources, as opposed to being a passive recipient (Downes, 20I0). In other words, lecturers should allow students the freedom and autonomy to control the content they want to learn (selection), the way in which they want to learn (sequence), and the speed at which they want to learn (pace) on the Zoom VCT (Hoadley and Jansen, 20I4; Mpungose, 20I9). Once they become active and identify their needs or identities, they can even host Zoom meetings.

Student assessment examines the student's ability to make connections between subject fields, ideas and concepts (Siemens and Downes, 2009). On the Zoom VCT, assessment is undertaken for the purpose of development rather than grading; it thus needs to be enjoyable for students (Black and Wiliam, 2009). The content taught during the official period of the lecture may change over time, based on new contributions in a subject area, and should be driven by learning outcomes to address student needs (Khoza, 20I9). This requires that students be driven by a personal and social rationale in making decisions as to what to learn and ascertaining how to make meaning of it (Downes, 2010).

Khoza (20I8) proposes that in addition to the 'what' and 'how' questions relating to learning, students should learn to address the 'who' and 'why' questions that help them to identify and understand their personal identities before they use the digital technology at their disposal. For example, before they use Zoom, they should understand what it offers that is relevant to them in order to use the functions that address their needs. This suggests that in a case where, for example, American policy makers decide to close down Zoom due to cyber-attacks, students who understand their identities are able to continue their learning. In other words, contact time allocated on Zoom must be organised to accommodate or suit every student's needs.

In seeking to address students' needs, South African universities, including the University of KwaZulu-Natal (UKZN) provided students from disadvantaged backgrounds with data bundles to enable them to connect to Zoom and the LMS. While this is commendable, many students face additional challenges that hamper online learning. Around $80 \%$ of students at UKZN cannot afford to pay their university fees. Various sources support these students financially, and provide them with food on campus. When students are forced to leave campus, they return home to overcrowded accommodation where there is a shortage of food and conditions are not 
conducive to studying. As noted previously, many of these students do not have access to Wi-Fi or the Internet. Providing data bundles does not address such challenges. This suggests the need for other sectors to assist universities to address the DD, especially during the lockdown emanating from COVID-I9.

Furthermore, it is essential that thorough planning (an e-learning policy, training and other issues) is undertaken before the Zoom VCT is adopted. It is vital to take students' experiences into account when adopting technology for learning. Thus, "getting users [students] to think about the process, the system (Zoom), and the way the system will be used well before and during the planning stages will assure greater and better utilization after the system is in place" (Cullen, 2008, p. I58). Table I below theorises the use of the Zoom VCT for e-learning drawing on the eight principles guiding the connectivism learning framework (Siemens and Downes, 2009).

Table 1. Principles of the Connectivism Learning Framework (Siemens and Downes, 2009) and Zoom E-Learning Qualities

\begin{tabular}{|l|l|}
\hline Connectivism Principles & Zoom E-Learning Qualities \\
\hline 1. Learning and knowledge rest on a diversity of opinions & Student-centred activities \\
\hline $\begin{array}{l}\text { 2. Learning is the process of connecting specialised nodes } \\
\text { or information sources }\end{array}$ & Home/residence \\
\hline 3. Learning may reside in non-human appliances & $\begin{array}{l}\text { Conferencing from desktop and } \\
\text { mobile }\end{array}$ \\
\hline $\begin{array}{l}\text { 4. The capacity to know more is more critical than what is } \\
\text { currently known }\end{array}$ & $\begin{array}{l}\text { Active student participation } \\
\text { (researchers) }\end{array}$ \\
\hline $\begin{array}{l}\text { 5. Connections need to be nurtured and maintained to } \\
\text { facilitate continual learning }\end{array}$ & $\begin{array}{l}\text { Social connections and Internet } \\
\text { connection }\end{array}$ \\
\hline $\begin{array}{l}\text { 6. The ability to see connections between fields, ideas, and } \\
\text { concepts is a core skill }\end{array}$ & Formative or peer assessment \\
\hline $\begin{array}{l}\text { 7. Currency (accurate, up-to-date knowledge) is the intent of } \\
\text { all connectivist learning activities }\end{array}$ & Produced and shared content \\
\hline $\begin{array}{l}\text { 8. Decision-making is itself a learning process. Choosing } \\
\text { what to learn and the meaning of incoming information } \\
\text { occurs through the lens of a shifting reality. Although there } \\
\text { is a right answer now, it may be wrong tomorrow because of } \\
\text { changes in the information climate affecting the decision }\end{array}$ & $\begin{array}{l}\text { - Social and personal rationale } \\
\text { - Lontact time }\end{array}$ \\
\hline
\end{tabular}

\section{The Literature on Students' Reflections on the Use of Educational} Technologies

Boud, Keogh, and Walker (2013) and Dewey (1933) argue that reflection (the phenomenon of interest in this study) in education is a useful selfintrospection process undertaken by students in isolation or in association with others to tackle challenges, events or situations. It helps students to "have control over the content and processes of their own work", and the VCT (Zoom) used (Zeichner and Liston, I987, p. 26). This suggests that reflection enables students to recapture, relive, make sense of, think about, and assess their experiences for effective use of the Zoom VCT for e-learning. A balance is required among different levels of reflection, such that students interrogate their practices and take action via formal reflection (based on written facts), informal reflection (based on connectedness and social ideas), and non-formal reflection (based on self-direction) in order to use any learning technology (Mpungose, 20I9; Van Manen, I99I). Mpungose (2020) concurs with Waghid and Davids (2019) that failing to pay equal attention to each of these levels of reflection can lead to the misapplication of technology (Zoom VCT), which can negatively affect university scholarship and integrity (Waghid and Davids, 20I9). This suggests that students should use formal reflections to establish how to use Zoom based on facts in written instructions in policy documents, manuals and others for effective e-learning. They should also be driven by informal and non-formal reflection to find support from training (university organised or from the Zoom official website) and other people from the surroundings, using their own identities (love, passion, creativity) to enhance e-learning.

Henderson, Selwyn, and Aston (20I7) argue that the rapid development of educational technologies such as LMS (Moodle), social media sites (Facebook) and VCT (Zoom) have altered the higher education landscape that is now technologically driven. This supports students' learning as digital natives (born in the digital age), allowing them to enjoy the benefits of connectedness and social interaction, equity of access to university resources, efficiency of content dissemination and personalisation of learning processes (Prensky, 200I; Siemens, 20I4). The recent literature describes students as being 'digital residents' and 'techno-savvy'; they are accustomed to experiencing digital technologies as seamless and always on, good at using technology and enjoy social spaces (Wright et al., 20I4). However, Selwyn (2016) agrees with Jones and Fox (2009) that not all students enjoy the benefits of educational technologies due to not only the first DD (access to the Internet and educational technologies) but also the second (attitude, skills, type of use) and third (Internet outcomes/benefits). 
While South African universities provide access to Wi-Fi (the Internet) to students on campus and in residential hostels, the majority of black disadvantaged students do not enjoy such access at home (Amory, 20I0; Waghid, Manthalu, Terblanche, Waghid, and Waghid, 2020). Thus, based on their location, subject area and institution, the majority of the country's students and its universities face difficulties in making 'good' use of digital technologies for effective e-learning (Henderson et al., 20I7; Mpungose, 2020). This raises questions about the roles, outcomes and consequences that these educational technologies (Zoom and others) are playing in students' learning. It suggests that higher education institutions and students should reflect on the use of any educational technology (including Zoom), to come up with practical support so that they may enjoy the benefits of new technologies.

Soykan and Şimşek's (20I7) review of the literature on the use of educational technologies found that Moodle, Canvas and Backboard LMS were most used by lecturers in universities between 2010 and 2016 , because communication was easy, quizzes (tests) were easily done and readings were easily distributed. However, the study concluded that students were not satisfied with the manner in which assessment was offered, customisation of LMS to ensure user friendliness, and the extent to which interaction was encouraged (discussion forum/chat room).

Bozanta and Mardikyan's (20I7) study at Bogazici University in Turkey on students' perceptions of the use of social media for learning revealed a paradigm shift. The study found that social media sites are students' 'daily bread' (from home to school), and that they are effective for learning because they improve interaction among peers and lecturers for content dissemination. The findings of these and other studies (Bradwell, 2009; Mpungose, 2020; Stirling, 20I6) suggest that universities should gradually move from formal educational technologies (LMS) to informal ones like social media sites, VCTs and others as students enjoy informal spaces (Basitere and Mapatagane, 20I8).

Mpungose (2020) agrees with Khoza (2019) that if students acknowledge the paradigm shift in the use of educational technologies, they schedule more time to develop new learning methods rather than complaining about the introduction of new technology (Zoom). Thus, in education the Zoom VCT can be viewed as the carrier of the curriculum (the plan for/of teaching), because it allows space for interaction or sharing of content among students and lecturers (Van den Akker, Branch, Gustafson, Nieveen, and Plomp, 20I2). According to Hoadley and Jansen (20I4), students need not only draw from a performance curriculum where learning is driven by the content in a particular discipline, and they are expected to memorise it to be recalled in the future, without any meaning-making process.
They also need to draw from a competence curriculum that enables them to control selection of the content, when and how they learn (pedagogy and sequence), and how quickly they learn (pace). This will help them to use the Zoom VCT pedagogically to address their needs as well as those of society and the subjects during the learning process (Apple, 2004; Tyler, 2013).

\section{Research Design and Methods}

Research Objective and Research Questions

In exploring students' reflections on the use of the Zoom VCT for learning at a South African university, our study addressed the following main research questions:

- What are students' reflections on use of the Zoom VCT at a South African university?

- What influenced students to reflect on the use of the Zoom VCT in the way they do?

Research Context, Sample, Design and Paradigm

The research questions were addressed through data generated from a case study of a research-intensive public university in KwaZulu-Natal. It has five campuses, including a School of Education, with a current enrolment of more than 7,000, including black, white, Indian, Coloured (mixed race) and other students. All students attend face-to-face lectures for a range of undergraduate degrees as well as postgraduate certificates, and Honours, Master's and Doctoral programmes. The School of Education has six disciplines, including education studies.

Students from the School of Education were recruited electronically through a flyer. After the consent forms were signed, 26 students were purposively and conveniently selected to participate in the study because they were accessible and were completing a curriculum studies module in the teacher education programme, and using the Zoom VCT for e-learning during the COVID-Is lockdown (Creswell and Poth, 20I7). Pseudonyms were assigned to protect the participants' identity and confidentiality (students being represented as Stu I, Stu 2, etc.) and they were informed that participation in the study was voluntary and that they were free to withdraw at any stage. The sample included eight first-year, six second-year, five third-year and seven final-year students.

We opted for a qualitative interpretive research design because it "captures the meaning of real-world events from the perspective of a study's participants" (Yin, 20I5, p. I2). This enabled the researchers to understand students' real reflections on their experiences of the use of the Zoom VCT. A case study design was used to explore their reflections in order to gain an in-depth understanding of the different, real contexts of students using 
the Zoom VCT for e-learning, by posing questions that not only provided information but also stimulated the students to reflect on why they engage in the use of the Zoom VCT (Creswell, 20I4).

\section{Research Methods and Analysis}

Data were generated from a Fulbright research project conducted in 20I92020 . A case study design uses multiple sources of data rather than relying on a single source, in order to gain in-depth understanding of the phenomenon under study (Yin, 20I5). Reflective activities with a short series of questions were emailed to students, seeking their reflections on the use of the Zoom VCT; these were completed within a period of a month (Cohen, Manion, and Morrison, 20I3). An online Zoom focus group interview with all 26 students was carried out within a month and lasted for 40 minutes. Trustworthiness (transferability, dependability, confirmability, and credibility) of the generated data was ensured.

Qualitative thematic analysis (inductive and deductive reasoning) was used to interpret the data in terms of the participants' definition of the situation, noting patterns, themes, categories, and regularities (Creswell and Poth, 20I7). The data generated by the two instruments were directly and openly coded from the recorded source, in order to avoid loss of meaning from transcription. We deductively mapped the codes into the set categories from the theoretical framework and the literature to form themes. An inductive process was employed to capture the codes which were not deductively analysed in the prior analysis, in order to form categories. Using these processes as a guide, categories were focused and sharpened to form the following three themes: Reflections on access to technological resources, Functional knowledge and skills, and Connectedness.

\section{Findings}

The study addressed connectedness in the use of the Zoom VCT among students enrolled in a curriculum studies programme by understanding their reflections (first objective) and what influenced their reflections on the use of this application (second objective).

\section{Reflections on Access to Technological Resources}

The participants reflected on the accessibility or availability of resources used for e-learning. For first-year Stu 3, access is a challenge: "we are not given laptop yet but we were promised since the beginning of first semester... I do not know how to use it ... I do not have a smart phone". All the first-year students agreed with this statement. The majority of the participants (I8 out of 26) stayed in remote areas. Third-year Stu I6 said: "I do not have both laptop and smart phone ... I cannot afford data bandwidth for Internet access... recently my mother committed suicide because she could not even afford to buy us food during this lockdown".

According to Stu 23, access to all the necessary resources determines effective e-learning: "... at home I have access to Wi-Fi, laptop and other resources ... we are just informed to use Moodle LMS and Zoom for e-learning". E-learning was not well-received by other participants after they had to vacate the university residences and return home. Stu 25 commented: "e-learning is frustrating me when I am home because I do not have necessary resources like laptops and Wi-Fi access ... my uncle is abusive in the house since he is not taking alcohol and not smoking because of lockdown regulations". However, it was evident that some resources were made available to students to access e-learning. Stu I reported: "We use WhatsApp groups, Skype, Zoom, video-recorded lectures, slides... I submit my assignment using Moodle LMS and via emails... but I hate quiz."

Functional Knowledge and Skills

Having the necessary resources for e-learning will not yield good results without proper training or planning. Stu I3 noted: "I did not know that I have to download Zoom app to my phone before I can join the meeting". Stu 2 said: "I only noticed that Zoom is plugged in on the Moodle LMS while I was submitting my assignment". Most of the participants who were in their first year of studies agreed that training would improve the use of Zoom and other technological resources. As Stu 7 indicated: "If training manuals can be provided to me, I can easily get to practice different functions of all Zoom and Moodle ...". However, ten of the 26 participants that had a good school background in computer literacy did not need training in order to use the technological resources. Stu I3 reported: “I use MacBook Pro [Apple laptop] to attend lecture using Zoom ... I enjoy to become a host during group session ... I enjoy chat function on Zoom". Nonetheless, some noted that, even if they knew how to use the resources, troubled home conditions or social problems stood in the way. For example, Stu I4 attested: "I can't even concentrate on doing my assessment tasks because my parents are always in quarrels and are busy with a divorce process", Stu 4 lamented: "I am always traumatised and I cannot concentrate because one of my cousins who is taking wonga [drugs] wanted to rape me two weeks back".

\section{Connectedness}

The Zoom VCT provides a synchronous environment where students and lecturers can engage in a class discussion to disseminate content. However, lengthy lectures can cause fatigue, with students losing focus/concentration. All of the participants agreed with Stu 26's observation that, “... I end up checking my Facebook post while the lecturer is sharing the screen with us [pre- 
senting the lecture] because there are no activities given to do". Similarly, Stu I9 said: "I also see people's faces ... I don't feel like am in class". In other words, students on a Zoom platform seem to be deprived of connectedness with their lecturers and learner autonomy; they do not feel as if they are in a real classroom (face-to-face) context. Furthermore, in order to save data, some students do not join Zoom using the video function and just use audio. Stu 9 said: "Listening to the voice only limits the interaction with the lecturer and other students on the platform ... I end up bored". Some students leave the lecture early due to challenges with Internet access; Stu I8 stated: "I only come in for first 30 minutes in first lecture to save data bundle for other lectures".

\section{Discussion of Findings}

The integration of emerging technological resources (VCT, SMS and others) into the curriculum for e-learning in a South African context was underexplored when their use for e-learning exploded onto the scene during the COVID-I9 lockdown (Amory, 20I0; Khoza and Biyela, 20I9; Mpungose, 2020). This study had theoretical and practical objectives. It sheds light on how students experienced the Zoom VCT after e-learning was imposed by the university due to the lockdown. It reflects social challenges relating to the DD (accessibility of technological resources), and connectedness as well as the knowledge and skills they deploy, that could inform how to promote e-learning in universities.

The findings show without the availability and accessibility of both hardware (physical resources) and software (online resources), e-learning is not attainable, as it resides in both human and non-human resources (Siemens and Downes, 2009). In other words, lecturers, students, and hardware and software resources need to be accessible for effective e-learning; missing one of these elements can disrupt efforts to promote e-learning (Mpungose, 2020; Polizzi, 2020). The majority of the study participants, particularly black first-year students, could not afford a laptop or smart phone and could thus not access Moodle and the Zoom VCT for e-learning. Their parents were unable to support them; indeed, one participant reported that his/her mother committed suicide during the lockdown because she had lost hope of being able to support her children. Waghid et al. (2020) note that disadvantaged black students' poor socio-economic background hinders e-learning (Mpungose, 2020; Waghid and Davids, 20I9). Myende and Ndlovu (2020) add that a one-size-fits-all approach (all students must be online) can result in further vulnerability and marginalisation of disadvantaged students.

However, the findings showed that e-learning is possible for those that have access to the necessary resources, with some participants stating that they had access to computers (laptops), smart phones, data bandwidth, the Zoom VCT, Moodle LMS and other resources. As noted by Magalhães, Ferreira, Cunha, and Rosário (2020), access to online resources enables interactive class discussions and immediate feedback, facilitates the presentation of lectures to large classes, and can enhance students' performance. It is thus recommended that all the necessary resources be made available to students before e-learning commences. This would level the playing field for effective e-learning.

Cullen (2008) argues that successful use of any educational technology (in this case the Zoom VCT) requires through planning before the technology is purchased and used. This includes the rationale for adopting a particular technology as well as issues around assessment, curriculum, instruction and others (Khoza and Mpungose, 20I8). Studies (Cuban, Kirkpatrick, and Peck, 200I; Jones, Reid, and Bartlett, 2008) have also shown that technology adoption may fail if is imposed on users (students) who are excluded from the planning process and receive inadequate training. The findings of this study showed that students were told to move online (using Moodle LMS and the Zoom VCT) without prior planning and negotiation, and other online resources such as WhatsApp and slide presentations were made available for use by students. However, no training or training manual was offered, which resulted in students struggling to use and enjoy some of Zoom's functions/features, such as the chat function. As shown in Figure 2 below, the majority of the participants were most active on the chat function of Zoom. Polizzi (2020) argues that effective e-learning involves students' reflections (experiences), and depends on the nature of digital knowledge and skills; this calls for thorough planning. Students should thus participate in decision-making relating to e-learning, and a clear e-learning policy should be formulated to provide direction to students. Finally, training is necessary in order to upgrade students' knowledge and skills.

Downes (2010) asserts that connectedness between students and lecturers in e-learning needs to be nurtured and maintained for smooth teaching and learning. Amory (2010) notes that this can be achieved by actively engaging students in online activities, such as letting them watch videos, play games and engage in other activities. The findings of this study showed that e-learning was difficult during the lockdown due to social factors such as physical and emotional abuse at home. While South Africa's crime statistics dropped during the lockdown, cases of gender-based violence remained high: "the number of complaints remained high and of concern ... over 2300 complaints had been registered" (Hough, 2020, p. I). This suggests that social challenges are a key hindrance to maintaining connection in e-learning. 
Figure 2. The Zoom VCT Features Most Used by the Participants

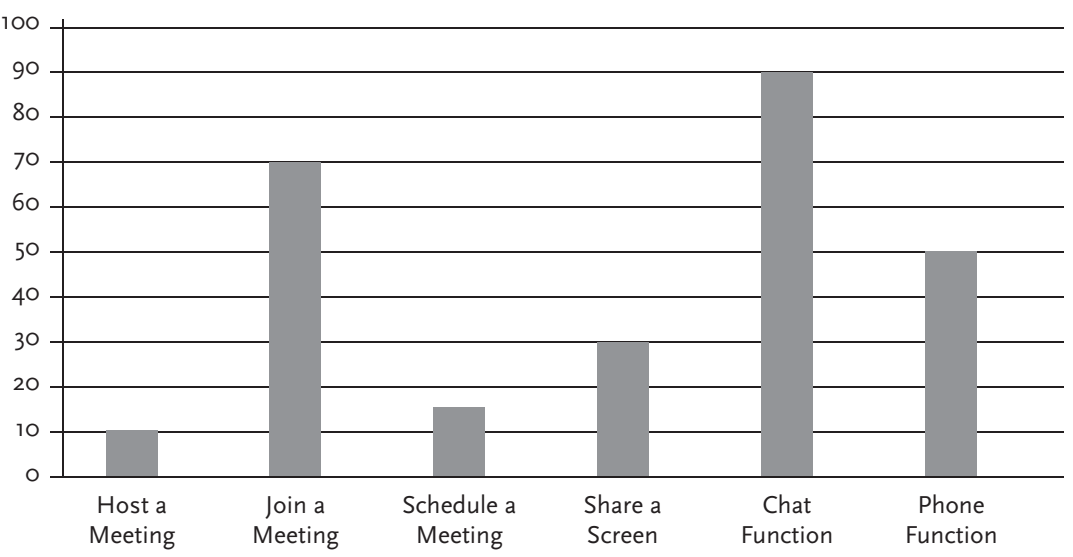

Khoza (20I9) argues that through self-introspection (non-formal reflection), which helps people to find their identities (love, passion, courage, creativity), students can come to know their strengths and limitations, which will assist them in improving their practices and engaging effectively in e-learning. In other words, effective e-learning starts with a student's inner self. Such reflection could help them to overcome the social barriers to e-learning.

The findings also showed that students were not given autonomy for self-direction during the learning process, to ensure connectedness. For instance, some were busy on social media sites (Facebook and WhatsApp) while the lecture was in progress, while others switched off the video mode so that they could move away from the screen because they were bored with the two-hour long lecture. This suggests that students are forced to attend online lectures instead of being motivated to actively participate to maintain connectedness. Several scholars (Anthony Artino and Ioannou, 2008; Artino and Stephens, 2007; Prensky, 200I) have suggested strategies to promote students' sense of autonomy and self-regulated learning online while maintaining connectedness. These include but are not limited to: (I) evaluation and individualised feedback on students' self-regulated learning; (2) online activities that are grounded in authentic problem-based activities to ensure motivation; (3) the scaffolding and timing of online discussions to focus on one particular skill/thinking at a time; and (4) group discussions for student collaboration.

This suggests that a student-centred pedagogy helps students to stay focused during lectures, and to combat e-learning (Zoom) fatigue (Hoadley and Jansen, 20I4; Mpungose, 2020). Siemens and Downes (2009) assert that connectivist and constructivist views of learning are among the most autonomous of instructional frameworks in the digital age that can be used to enhance effective e-learning. In connected e-learning, students must be engaged in a dialogue, and be encouraged to nurture their natural curiosity and to have control over the lecture (Bernstein, I999). In other words, e-learning must be democratic to enhance problem-based learning rather than the 'banking' (knowledge depository) concept of learning, to ensure self-direction (Dewey, I933; Freire, 2000).

\section{Conclusion and Implications for Education}

The main purpose of the study was to explore students' reflections on the use of the Zoom VCT for e-learning in a South African university context. The findings offer university management and students a set of practical, empirically-based guidelines to achieve effective e-learning for all. It was found that access to technological resources varies greatly according to students' socio-economic backgrounds and this creates a social divide as well as the DD that hinders effective e-learning. Students' knowledge and skills in the use of hardware and software as well as their level of self-efficacy in e-learning also have a significant impact. Based on the findings, the following theoretical and practical recommendations are proposed for effective e-learning:

- Students should be provided with the necessary technological resources, which may include but not be limited to computers (laptops), smart phones, routers with sufficient data bundles, recorded lectures on different storage devices and others.

- Students should receive the necessary training to enhance their knowledge and skills in both software resources (Moodle LMS and the Zoom VCT).

- Connectivism is a useful framework for e-learning in the digital age, since it promotes the social construction of knowledge. It requires students to be driven by their inner self through their self-identity, in order to be self-motivated to cross boundaries and attain effective e-learning.

- The university should develop an e-learning policy in order to ensure fitness for purpose. Without a well-designed plan, challenges relating to the social divide and the DD will escalate, causing students to experience anxiety, resistance and frustration.

One of the limitations of this study, as with other qualitative research, is that it was small in scale; thus, its findings are contextual and cannot be generalised. Further research is required to investigate the use of emerging technologies like the Zoom VCT. 


\section{References}

Ahluwalia, S. (2020). There is really no other way to collaborate and communicate other than a great video conferencing solution, and we use Zoom. Retrieved from https://zoom.us/customer/technology

Amory, A. (2010). Education Technology and Hidden Ideological Contradictions. Educational Technology and Society 13(I), 69-79.

Anderson, T. (2016). Theories for learning with emerging technologies. Emerging technologies in distance education 7(I), 7-23.

Ansaldo, M. (2020). Skype vs. Zoom: Which is best for working from home? Retrieved from https://www.pcworld.com/article/3536688/ skype-vs-zoom-which-is-best-for-working-from-home.html

Apple, M. W. (2004). Ideology and curriculum. London: Routledge.

Artino, A., and Ioannou, A. (2008). Promoting academic motivation and selfregulation: Practical guidelines for online instructors. Paper presented at the Society for Information Technology and Teacher Education international conference.

Artino, A., and Stephens, J. M. (2007). Motivation and self-regulation in online courses: A comparative analysis of undergraduate and graduate students. Paper presented at the annual meeting of the Association for Educational Communications and Technology, Anaheim, CA.

Basitere, M., and Mapatagane, N. (20I8). Effects of a Social Media Network Site on Students' Engagement and Collaboration: A case study of WhatsApp at a University of Technology. Paper presented at the ECSM 20I8 5 th European Conference on Social Media

Bell, F. (20II). Connectivism: Its place in theory-informed research and innovation in technology-enabled learning. The International Review of Research in Open and Distributed Learning 12(3), 98-II8.

Bernstein, B. (I999). Vertical and horizontal discourse: An essay. British Journal of Sociology of Education 20(2), I57-I73.

Black, P., and Wiliam, D. (2009). Developing the theory of formative assessment. Educational Assessment, Evaluation and Accountability (formerly: Journal of Personnel Evaluation in Education) 21(I), 5-3I.

Boud, D., Keogh, R., and Walker, D. (2013). Promoting reflection in learning: A model. Boundaries of Adult Learning 1, 32-57.

Bozanta, A., and Mardikyan, S. (20I7). The effects of social media use on collaborative learning: A case of Turkey. Turkish Online Journal of Distance Education 18(I), 96-IIO.

Bradwell, P. (2009). The edgeless university: Why higher education must embrace technology. Retrieved from https://www.yumpu.com/en/ document/read/23669929/the-edgeless-university-why-higher-education-must-embrace-jisc
Chetty, R. L. (2020). SA schools need to turn to online tools like Zoom to assist Matrics during COVID-I9 outbreak. Retrieved from http://htxt. co.za/2020/03/sa-schools-need-to-turn-to-online-tools-like-zoom-toassist-matrics-during-covid-I9-outbreak/

Cohen, L., Manion, L., and Morrison, K. (2013). Research methods in education. London: Routledge.

Creswell, J. (20I4). Qualitative inquiry and Research Design: Choosing among five approaches (3 ed.). California: SAGE Publications, Inc.

Creswell, J., and Poth, C. N. (20I7). Qualitative inquiry and research design: Choosing among five approaches. California: SAGE Publications, Inc.

Cuban, L., Kirkpatrick, H., and Peck, C. (200I). High access and low use of technologies in high school classrooms: Explaining an apparent paradox. American educational research journal 38(4), 8I3-834.

Cullen, M. (2008). Primer on technology and behaviour: Cyber Sins and Digital Good Deeds: A Book about Technology and Ethics. New York: Haworth Information Press.

Dewey, J. (1933). How we think: A restatement of the reflective thinking to the educative process. New York, NY: MacMillan.

DHET. (2020). Measures to deal with the Coronavirus COVID-I9 in the post-school education and training sector. Retrieved from https:// www.gov.za/speeches/minister-higher-education-science-and-innovation-statement-measures-deal-covid-ro-threat

Downes, S. (2010). New technology supporting informal learning. Journal of Emerging Technologies in Web Intelligence 2(I), 27-33.

Freire, P. (2000). Pedagogy of the oppressed. New York: Bloomsbury Publishing.

Henderson, M., Selwyn, N., and Aston, R. (20I7). What works and why? Student perceptions of 'useful' digital technology in university teaching and learning. Studies in Higher Education 42(8), I567-I579.

Hoadley, U., and Jansen, J. (20I4). Curriculum: Organizing knowledge for the classroom. Cape Town: Oxford University Press Southern Africa.

Hough, A. (2020). Cele says number of murder, rape, assault cases have dropped during lockdown. Retrieved from https:/www.msn.com/ en-za/news/national/cele-says-number-of-murder-rape-assaultcases-have-dropped-during-lockdown/ar-BBı2dSje

Jones, S., and Fox, S. (2009). Generations online in 2009: Pew Internet and American Life Project Washington, DC.

Jones, K. O., Reid, J., and Bartlett, R. (2008). Cyber cheating in an information technology age. Digithum 10, 19-29.

Khoza, S., and Biyela, A. T. (2020). Decolonising technological pedagogical content knowledge of first year mathematics students. Education and Information Technologies 25(2020), 2665-2679. 
Khoza, S., and Mpungose, C. (2018). Use of the Moodle Curriculum by Lecturers at a South African University. Paper presented at the ICEL 20I8 I3th International Conference on e-Learning.

Khoza, S. (20I8). Can Teachers' Reflections on Digital and Curriculum Resources Generate Lessons? Africa Education Review 1(20I8), I-I6.

Khoza, S. (2019). Lecturers' reflections on curricular spider web concepts transformation strategies. Transformation of Higher Education Institutions in Post-Apartheid South Africa 1, 15-26.

Kop, R., and Hill, A. (2008). Connectivism: Learning theory of the future or vestige of the past? The International Review of Research in Open and Distributed Learning 9(3), I-I3.

Magalhães, P., Ferreira, D., Cunha, J., and Rosário, P. (2020). Online vs traditional homework: A systematic review on the benefits to students' performance. Computers and Education 152, I-7.

Mpungose, C. (2020a). Is Moodle or WhatsApp the preferred e-learning platform at a South African university? First-year students' experiences. Education and Information Technologies 25(2), 927-94I. doi:Io.I007/ sio639-0i9-10005-5

Mpungose, C. (2020b). Is Moodle a platform to decolonise the university curriculum? Lecturers' reflections. Africa Education Review I7(I), IOO-II5.

Myende, P., and Ndlovu, N. (2020). COVID-I9 and Online Teaching and Learning: A Double Dilemma for Rural Students. Retrieved from http:// ndabaonline.ukzn.ac.za/UkzndabaStory/Vol8-Issuei3/COVID\%20 I9\%20and\%20Online\%20Teaching\%2oand\%2oLearning\%20A\%20 Double\%2oDilemma\%2ofor\%2oRural\%2oStudents

Polizzi, G. (2020). Digital literacy and the national curriculum for England: Learning from how the experts engage with and evaluate online content. Computers and Education, 103859

Prensky, M. (200I). Digital natives, digital immigrants part I. On the horizon 9(5), I-6.

Selwyn, N. (20I6). Minding our language: why education and technology is full of bullshit... and what might be done about it. London: Taylor and Francis.

Siemens, G. (2005). Connectivism: A Learning Theory for the Digital Age http://www. elearnspace. org. Articles/connectivism.htm (Accessed:01/03/ 2007). Retrieved from https://jotamac.typepad.com/jotamacs_weblog/ files/Connectivism.pdf

Siemens, G. (20I4). Connectivism: A learning theory for the digital age. Journal of Emerging Technologies in Web Intelligence 2(1), 27-33.

Siemens, G., and Downes, S. (2009). Connectivism and connective knowledge. International Journal of Instructional Technology and Distance Learning 2(I), 3-IO.
Soykan, F., and Şimşek, B. (20I7). Examining studies on learning management systems in SSCI database: A content analysis study. Procedia computer science $120,87 \mathrm{I}-876$.

Stirling, E. (2016). Technology, time and transition in higher education - two different realities of everyday Facebook use in the first year of university in the UK. Learning, media and technology 41(I), IOO-II8.

Strauss, V. (2020). As schooling rapidly moves online across the country, concerns rise about student data privacy. Retrieved from https://www. washingtonpost.com/education/2020/03/20/schooling-rapidly-moves -online-across-country-concerns-rise-about-student-data-privacy/

Tillman, M., and Willings, A. (2020). What is Zoom and how does it work? Plus tips and tricks. Retrieved from https://www.pocket-lint.com/ apps/news/I5I426-what-is-zoom-and-how-does-it-work-plus-tips-andtricks

Tyler, R. (2013). Basic principles of curriculum and instruction. Chicago: University of Chicago Press.

Van den Akker, J., Branch, R., Gustafson, K., Nieveen, N., and Plomp, T. (20I2). Design approaches and tools in education and training. Berlin: Springer Science and Business Media.

Van Deursen, A. J., and van Dijk, J. A. (20I9). The first-level digital divide shifts from inequalities in physical access to inequalities in material access. New media and society 21(2), 354-375.

Van Manen, M. (I99I). Reflectivity and the pedagogical moment: the normativity of pedagogical thinking and acting. J. Curriculum Studies $23(6), 507-536$.

Waghid, Y., and Davids, N. (2OI9). On the polemic of academic integrity in higher education. South African Journal of Higher Education 33(I), I-5.

Waghid, Y., Manthalu, C. H., Terblanche, J., Waghid, F., and Waghid, Z. (2020). In Becoming Reflexive: Implications for Education. In: Cosmopolitan Education and Inclusion, pp. I05-I20. Springer.

Warschauer, M. (2002). Reconceptualizing the digital divide. First Monday. Retrieved from https://firstmonday.org/ojs/index.php/fm/article/ download/967/888?inline $=\mathrm{I}$

Weiner, Y. (20I7). The Inspiring Backstory of Eric S. Yuan, Founder and CEO of Zoom. Retrieved from https://medium.com/thrive-global/ the-inspiring-backstory-of-eric-s-yuan-founder-and-ceo-of-zoom$98 \mathrm{~b} 7 \mathrm{fab} 8 \mathrm{cacc}$

WHO. (2020). WHO Director-General's opening remarks at the media briefing on COVID-I9 - II March 2020. Retrieved from https:// www.who.int/dg/speeches/detail/who-director-general-s-openingremarks-at-the-media-briefing-on-covid-Io---II-march-2020 
Yin, R. K. (20I5). Qualitative research from start to finish. New York: Guilford Publications.

Zoom Support. (2020). Zoom Support Help Center. Retrieved from https: //support.zoom.us/hc/en-us?_ga=2.238265920.I741005465.I588 OII244-53I2520II.I580767885 